\title{
7 Crowdfunding
}

\subsection{General Remarks}

The purpose of this book is to find out what should be done to increase the number of companies with publicly-traded shares and retail investors' direct share ownership. The underlying assumption is that a wider distribution of shares and retail investors' direct share ownership can help to reduce financial inequalities. Crowdfunding was not proposed as a solution in Chapter 6 .

In this Chapter, we will study crowdfunding as a potential solution. Could crowdfunding help to increase the number of companies with publicly-traded shares? Could crowdfunding help to increase retail investors' direct equity investments? Are there design principles that regulators should use for this purpose?

Crowdfunding. Crowdfunding consists of several methods of raising funds. The common denominator is the existence of three kinds of participants: a crowdfunding platform; crowdfunding campaign creators; and contributors, that is, the crowd. ${ }^{1}$ The innovative aspect of crowdfunding is the use of an Internet-based two-sided platform.

Crowdfunding can help campaign creators such as start-ups to raise funding from retail investors. There is hype: "Through crowdfunding, Main Street has the ability to get involved in an activity previously reserved to Wall Street actors: financing new and emerging business ventures."2

However, one may ask whether crowdfunding can help retail investors. On one hand, crowdfunding platforms provide many services that can benefit retail investors. Crowdfunding platforms act as gatekeepers and information intermediaries, broker investments, and provide contracts. ${ }^{3}$ On the other, crowdfunding does not seem to be able to provide financial security for retail investors. Only some forms of crowdfunding are investments. Moreover, the volumes of financial return crowdfunding are still low in the EU and the US. ${ }^{4}$

1 Gabison GA (2015) p 362.

2 Heminway JM (2017) p 193.

3 Hornuf L, Klöhn L, Schilling T (2018) pp 518-519 on the many functions of crowdinvesting platforms.

4 See even Hofmann C (2018) p 229: "The conventional, early-stage crowdfunding model may hold benefits for companies that are barred from or have no reasonably priced access to traditional ways of financing. The model may also pay off for the platforms as long as it generates at least modest returns. However, it is questionable whether non-professional investors should take on disproportionately high risks in exchange for the prospect of rather modest returns."

Ә OpenAccess. (C) 2022 Petri Mäntysaari, published by De Gruyter. (cc))BY-NC-ND This work is licensed under the Creative Commons Attribution-NonCommercial-NoDerivatives 4.0 International License.

https://doi.org/10.1515/9783110761108-008 
Crowdfunding platforms. Crowdfunding platforms are two-sided platforms. ${ }^{5}$ To succeed in the long term, they should generate value to both sides.

As intermediaries, crowdfunding platforms provide core and ancillary services. ${ }^{6}$ One of the core services in financial retum crowdfunding is linking funding demand and supply, or the demand for funding and the functional equivalents of funding. ${ }^{7}$

The operators of crowdfunding platforms are in the crowdfunding business to make money. There is competition between platform operators. There are already hundreds of crowdfunding platforms just in the EU. ${ }^{8}$ Many operators of crowdfunding platforms are start-ups or young firms themselves.

Platform operators can choose between alternative business models. ${ }^{9}$ They can charge fees as intermediaries, or obtain part of the issued securities. Where the platform operator is a start-up or a young firm, it needs to focus on increasing the number of users and the size of the platform. Its incentives are short-term as far as any particular issuing is concerned, ${ }^{10}$ but long-term as far as the reputation of the platform and the viability of its model are concerned. For traditional financial intermediaries, the operation of a crowdfunding platform can provide cross-selling opportunities. The most important asset in digital economy is user information, which is increased by the scale and scope of the platform. The large number of crowdfunding platforms indicates that there will be consolidation in the future.

Forms of crowdfunding. Funding can be raised in many ways. In broad terms, crowdfunding can take the form of donations, rewards/sponsorship, preselling/ pre-ordering, lending, or equity. ${ }^{11}$ Crowdfunding instruments can even be hybrid or convertible instruments, ${ }^{12}$ or derivatives such as SAFEs. ${ }^{13}$

5 For the US definition of "platform”, see Regulation Crowdfunding, §227.300(4).

6 For the ancillary services of crowdfunding platforms, see Gabison GA (2015) p 363-365; Hornuf L, Klöhn L, Schilling T (2018) pp 518-519; FCA (2018) paragraph 3.23.

7 In a Swedish government study, the core service was described as follows: "The platform company operates as intermediary, linking capital seekers and investors and enabling them to carry out transactions with each other.” SOU 2018:20, Gräsrotsfinansiering: Betänkande av Utredningen om gräsrotsfinansiering, p 29.

8 Action Plan on Building a Capital Markets Union. Communication from the Commission, $\operatorname{COM}(2015) 468$ final, section 1.1.

9 FCA (2018) Chapter 3 and Table 1; Zetzsche DA, Preiner C (2018) pp 237-238.

10 Hofmann C (2018) p 229.

11 OECD (2015c) pp 82-83; UNDP (2017); Hofmann C (2018) p 224. See also Gabison GA (2015) p 363; Williamson JJ (2013) p 2073 on how companies adapted to restrictive SEC rules in the past. 12 Wroldsen JS (2017); Hofmann C (2018) p 225. 
In the US, donations used to be the predominant source of crowdfunding financing. Kickstarter and Indiegogo were early crowdfunding platforms for rewards and donations. The issuing of securities fell within the scope of the general securities law regime.

In Europe, crowdfunding is dominated by lending. ${ }^{14}$ The UK has the largest domestic crowdfunding market in Europe. ${ }^{15}$ However, loan-based crowdfunding in the UK and the US pales in comparison with loan-based crowdfunding in China that is estimated to be larger than loan-based crowdfunding in the UK and the US combined. ${ }^{16}$

Equity-based crowdfunding emerged in Europe before it became legal in the US. ${ }^{17}$ However, according to a study by Cambridge Centre for Alternative Finance and University of Agder, the volume of equity-based crowdfunding was still very low in Europe in 2017. The top three countries in equity-based crowdfunding were Finland (€51 m), Sweden (€48 m), and France (€34 m). ${ }^{18}$ Such low volumes are a drop in the ocean of equity markets. In Germany, the market leaders for equity crowdfunding between 2012 and 2015 included Seedmatch and Companisto. ${ }^{19}$ In 2019, Companisto moved from crowdfunding to curation and the pooling of angel investments (section 6.4.15).

Crowdfunding as a form of funding, consumption or investment. From the perspective of contributors, participating in crowdfunding can be a form of consumption or investment.

13 Green JM, Coyle JF (2016) p 174: "Of the 96 issuers to launch crowdfunding offerings through August 31, 2016, 30 issuers (approximately 31\%) chose to offer convertible securities (such as convertible notes, SAFEs, or similar instruments) to prospective crowdfunding investors. Ninety percent of the convertible securities used were SAFEs." Green JM, Coyle JF (2016) pp 169-170: "Outside of the crowdfunding context, there are situations in which the SAFE may be a sensible instrument for startups to use when fundraising ... [W] argue that the most promising solution to the problems ... is for the funding portals to remove the SAFE from their menus of financing instruments."

14 SOU 2018:20, Gräsrotsfinansiering: Betänkande av Utredningen om gräsrotsfinansiering, p 117, citing Cambridge Centre for Alternative Finance.

15 Ibid., p 118.

16 Ibid., p 107.

17 Gabison GA (2015) p 363.

18 Ziegler T, Sneor R, Wenzlaff K, Odorović A, Johanson D, Hao R, Ryll L (2019) p 35.

19 Between 7 June 2012 and 27 April 2015, Seedmatch and Companisto accounted for around $75 \%$ of the total equity crowdfunding capital raised in Germany according to Dorfleitner G, Hornuf L, Weber M (2017). 
Donations, rewards, and the purchase of products can only be regarded as a form of consumption. ${ }^{20}$ Many contributors are not looking for financial security. Sponsoring an exciting project or pre-ordering new things may be a form of selffulfilment and bring social rewards. For issuers, donations and rewards can be easier to organise, because the issuing of securities tends to be constrained by securities laws.

Only lending and equity crowdfunding can be investments. Crowdfunding does not provide a very good form of investment at the moment. The volume of investment crowdfunding is low. Investment crowdfunding can be regarded as a marginal phenomenon in Europe and the US. ${ }^{21}$ Even if crowdfunding grew at a very high speed, the amount of funds that could be raised through crowdfunding would be marginal in the light of the large financing needs of SMEs in the foreseeable future.

Because of the very high failure rate of start-ups ${ }^{22}$ and the absence of a secondary market, equity crowdfunding is akin to sponsoring or gambling that are forms of consumption. ${ }^{23}$

Loan-based instruments can be expected to be more suitable for retail investors. However, loan-based crowdfunding or convertible instruments will not work for technology start-ups that focus on growth (see section 7.4) and crowdfunding contributors will not get a share of the rising value of successful start-ups unless they invest in stocks. ${ }^{24}$

From the perspective of a start-up or an aspiring entrepreneur, crowdfunding can be a form of funding regardless of the choice between donations, preselling, loans, or equity, and regardless of the fact that the overall volumes are low. Moreover, the firm may benefit from the contributors' ancillary services regardless of the form of crowdfunding. In non-equity crowdfunding, non-shareholders can help to create hype, increase business, and act as a low-powered monitoring mechanism through social media. Contributors provide similar ancillary services in equity crowdfunding.

20 See Gabison GA (2015) p 368 on how contributors can invest because of many non-financial reasons. See also Chiu IHY, Greene EF (2019) on sustainable and social finance projects.

21 Ziegler T, Sneor R, Wenzlaff K, Odorović A, Johanson D, Hao R, Ryll L (2019).

22 Gilson RJ (2003) p 1076; Klöhn L, Hornuf L, Schilling T (2016); Hofmann C (2018) p 228: “The risk of total or substantial losses is very real as nascent companies are subject to high failure rates. Data from the Singaporean Department of Statistics reveals that only about $50 \%$ of start-ups survive to their 5th year."

23 It is customary to regard equity crowdfunding as a form of investment. See, for example, Zetzsche DA, Preiner C (2018) pp 221-222.

24 See, for example, Herdrich N (2015). 
Crowdfunding might therefore increase the number of start-ups. With some luck, some of them will grow into successful firms. ${ }^{25}$ This said, much more than crowdfunding would be needed to increase the number of companies with publicly-traded shares, retail investors' direct equity investments in growth firms, and reasonable long-term investment opportunities. ${ }^{26}$

The regulation of securities-based crowdfunding. The regulatory framework of securities-based crowdfunding consists of external rules and the platform's internal rules.

External rules depend on the country. Securities-based crowdfunding may be constrained by general restrictions on the right to solicit funds from the public and by prospectus requirements that are triggered when securities are issued to the public. ${ }^{27}$ The operation of a crowdfunding platform may be a regulated activity $^{28}$ and require an authorisation or registration, compliance with minimum capital requirements, the filing of information with the regulatory authorities, and disclosures to customers. ${ }^{29}$

External rules are complemented by internal rules. The operator of a crowdfunding platform makes its own rules. Platform users cannot use the platform unless they accept the operator's rules. In addition to facilitating transactions on the platform, the platform operator's rules can help to prevent fraud and increase trust.

Both the US government and the EU have recognised the potential benefits of crowdfunding. Regulation has nevertheless been influenced by the unclear nature of crowdfunding. In a 2014 Communication, ${ }^{30}$ the European Commission listed the lack of regulatory transparency as the source of key challenges for

25 See also FESE (2018) on the FESE's position: “Crowdfunding can be a positive element for enterprise funding in general and for reviving public corporate financing, especially since it can help: • Grow the pipeline of companies preparing for an IPO; • Build a stronger equity culture in Europe, which would eventually have a positive impact on the participation of retail investors in public equity markets, which is positively correlated with better access of SMEs to IPOs; and, • Revive the local ecosystems necessary for IPOs of smaller companies."

26 Ibid.: "To fully meet the needs of European companies, with a focus on those that have the highest contribution to job growth, the EU needs to continue working on a comprehensive strategy on how to boost equity financing at all stages of the funding escalator."

27 Hofmann C (2018) p 236 on the prospectus requirement under Singapore law and how companies prefer to avoid it.

28 See ibid., pp 233-234 on licensing requirements under Singapore's Securities and Futures Act (SFA).

29 See ibid., p 239.

30 Unleashing the potential of Crowdfunding in the European Union. Communication from the Commission, $\operatorname{COM}(2014) 172$ final. 
crowdfunding in the EU. ${ }^{31}$ In the US, equity crowdfunding used to be an illegal activity under securities law ${ }^{32}$ before the adoption of Regulation Crowdfunding. ${ }^{33}$

One may ask whether, or to what extent, it would be meaningful to apply to crowdfunding transactions standards generally applicable to securities investments.

In this Chapter, we will study the regulation of crowdfunding in the EU (section 7.2) and the US (section 7.3) as well as crowdfunding practices (section 7.4). Moreover, we will propose some design principles for the crowdfunding market (section 7.5).

\subsection{The Regulation of Securities-Based Crowdfunding in the EU}

Generally, there is a choice between regulating either crowdfunding products or platforms. If crowdfunding products fall within the scope of complex piece-meal regulation, crowdfunding can be hampered. The same can be said of the piecemeal regulation of crowdfunding functions. Crowdfunding levels can be increased by regulating crowdfunding platforms or the operators of crowdfunding platforms rather than products or functions. ${ }^{34}$ Since the operator of the platform acts as a gatekeeper, it is regarded as the most efficient focal point of regulation. ${ }^{35}$ Regulating platforms or platform operators would require focusing on authorisation and prudential requirements.

European financial markets generally are regulated on a piece-meal basis. ${ }^{36}$ Crowdfunding could therefore fall within the scope of various pieces of European legislation each designed to address a particular sector or context.

31 Ibid., section 3.1. See also Gabison GA (2015) pp 360-361.

32 Williamson JJ (2013) p 2073; Kitch EW (2014) p 892.

33 SEC Release No. 33-9974 (Oct. 30, 2015) (Regulation Crowdfunding).

34 Zetzsche DA, Preiner C (2018) p 237.

35 See ibid., pp 238-239; Klöhn L, Hornuf L, Schilling T (2016): “[A]s classic gatekeepers, funding portals offer excellent regulatory access to ensure that the market functions properly. That is why their duties are one cornerstone of the CROWDFUND Act and the UK equity crowdfunding regulation."

36 Unleashing the potential of Crowdfunding in the European Union. Communication from the Commission, COM(2014) 172 final, section 3.1.2; Gabison GA (2015) p 376-386; Zetzsche DA, Preiner C (2018) p 230. 
The Member States of the EU have regulated equity crowdfunding in different ways in their national laws. ${ }^{37}$ Some differences exist due to the fact that equity crowdfunding can fall within the scope of many EU directives and the Member States have some discretion when implementing EU directives in national law.

The piece-meal approach to regulation and differences between national laws have hampered cross-border crowdfunding transactions in the EU. ${ }^{38}$ In fact, crowdfunding has largely been a local activity. The volume of cross-border equity crowdfunding in the EU was mere $€ 1.8$ million in $2014 .^{39}$

The European Commission did not want to regulate crowdfunding too early. In its 2014 Communication, the European Commission stated that "[t]he EU should strike a careful balance between the objectives of investor protection and continued expansion of crowdfunding. Premature regulation could hamper, not foster, the growth of this fast-growing and innovative funding channel." 40 Moreover, the European Commission said that "[t]he main issues EU legislation addresses with regards to all types of crowdfunding include anti-money laundering, advertising, consumer protection and - where relevant - intellectual property protection". ${ }^{41}$ Different national rules might be in place where EU legislation does not apply: "This is the case in particular for charitable giving and donations, rewards-based and pre-sales models of crowdfunding."42

In March 2018, as part of its FinTech Action plan ${ }^{43}$, the European Commission presented a proposal for a Regulation on European Crowdfunding Service Providers (ECSP) for Business. ${ }^{44}$ In the impact assessment that accompanied the 2018 proposal, the Commission recognised that EU crowdfunding markets for business finance were both underdeveloped compared to other major economies and unable to properly operate cross-border. Crowdfunding platforms were unable to scale up and freely provide their services on a pan-European level due to fragmented and conflicting regulatory regimes. Investors refrained from en-

37 See Government Bill 46/2016 on the Finnish Crowdfunding Act, section 2.2.1; SOU 2018:20, Gräsrotsfinansiering: Betänkande av Utredningen om gräsrotsfinansiering, Chapter 4; Klöhn L, Hornuf L, Schilling T (2016) on German law.

38 See European Crowdfunding Network AISBL (2017).

39 Zetzsche DA, Preiner C (2018) p 228.

40 Unleashing the potential of Crowdfunding in the European Union. Communication from the Commission, $\operatorname{COM}(2014) 172$ final, section 1.1.

41 Ibid., section 3.1.1.

42 Ibid., section 3.1.1.

43 FinTech Action plan: For a more competitive and innovative European financial sector. Communication from the commission COM (2018) 109 final.

44 Proposal for a Regulation of the European Parliament and of the Council on European Crowdfunding Service Providers (ECSP) for Business, COM(2018) 113 final. 
gaging cross-border due to a lack of trust in those platforms and the fragmented regulatory frameworks. ${ }^{45}$

We can have a look at the piece-meal regulatory framework before turning to the sector-specific regulation of crowdfunding platforms in the EU.

Electronic commerce, consumer protection. There is a large regulatory framework for the protection of consumers in digital economy in the EU.

According to the European Commission, 46 "platforms charging money to successfully financed projects may engage in e-commerce and thus fall under the e-Commerce Directive. The Directive on misleading and comparative advertising provides minimum harmonisation for misleading marketing practices in a business to business context. Consumers are protected against misleading and aggressive crowdfunding practices by the Directive on unfair commercial practices, prohibiting certain marketing practices. If standard terms and conditions used by crowdfunding operators contain unfair clauses, then these are not binding on participating consumers under the Unfair Contract Terms Directive."47

In business-to-consumer transactions, the trader must comply with disclosure duties under the e-Commerce Directive and the Consumer Rights Directive. ${ }^{48}$

In 2019, the EU adopted two new consumer protection directives. The Sale of Goods Directive ${ }^{49}$ applies to "sales contracts between a consumer and a seller". According to its wording, the Sale of Goods Directive can thus apply to crowdfunding pre-ordering or pre-selling. The Digital Content Directive ${ }^{50}$ does not apply to financial services. ${ }^{51}$

Donations. Donations can take many forms. First, there can be calls to the public to supply non-monetary contributions to the realisation of a project. For example, the crowd may be asked to contribute with their skills to make a movie project happen. Second, there can be monetary contributions.

45 Ibid., Explanatory memorandum, section 3.

46 Unleashing the potential of Crowdfunding in the European Union. Communication from the Commission, $\operatorname{COM}(2014) 172$ final, section 3.1.1.

47 The cited directives were Directive 2000/31/EC (Directive on electronic commerce); Directive 2006/114/EC (Directive concerning misleading and comparative advertising); Directive 2005/29/ EC (Directive concerning unfair business-to-consumer commercial practices); Directive 93/13/ EEC (Directive on unfair terms in consumer contracts).

48 Directive 2011/83/EU (Directive on consumer rights).

49 Directive (EU) 2019/771 (Directive on certain aspects concerning contracts for the sale of goods).

50 Directive (EU) 2019/770 (Directive on certain aspects concerning contracts for the supply of digital content and digital services).

51 Recital 30 and point (e) of Article 3(5) of Directive (EU) 2019/770 (Digital Content Directive). 
There can be legal restrictions on donations in the form of monetary contributions depending on the Member State. This can be illustrated with Finnish law. Under Finnish law, you need a permit to solicit funds from the public in the form of donations. The permit is not available for commercial purposes or to an individual. $^{52}$ Sales or pre-sales are thus legally safer. For compliance reasons, it would be necessary to ensure that the price does not include any donation element. For example, the absence of a minimum price and the freedom of contributors to choose the price would be regarded as a donation. In practice, the regulation of donations has made it difficult for large crowdfunding marketplaces such as Kickstarter to operate in Finland. The Finnish Crowdfunding Act of 2016 only applies to securities-based crowdfunding.

Financial return crowdfunding. There are restrictions on financial return crowdfunding such as crowdlending and equity crowdfunding. In the EU, these forms of crowdfunding are governed by a very fragmented regulatory framework.

In its 2014 Communication, ${ }^{53}$ the European Commission listed the most important pieces of EU legislation that might apply to financial return crowdfunding. They included what are now the Prospectus Regulation, the Payment Services Directive (that might apply to crowd sponsoring depending on the business model), MiFID II, the Capital Requirements Directive (CRD IV) and Regulation (CRR), the Directive on Alternative Investment Fund Managers (AIFMD), the Consumer Credit Directive, the Directive on the Distance Marketing of Financial Services, the European Venture Capital Regulation (EuVECA), and the Regulation on European Social Entrepreneurship Funds (EuSEF). ${ }^{54}$ There are additional rules at national level.

Securities-based crowdfunding platforms generally can be authorised under MiFID II and benefit from a passport to carry out regulated services and activities throughout the EU. ${ }^{55}$

52 Section 6 of lag om penninginsamlingar (255/2006).

53 Unleashing the potential of Crowdfunding in the European Union. Communication from the Commission, $\operatorname{COM}(2014) 172$ final, section 3.1.2.

54 Regulation 2017/1129 (Prospectus Regulation); Directive 2015/2366/EU (PSD2); Directive 2014/ 65/EU (MiFID II), Directive 2013/36/EU (CRD IV), Directive 2011/61/EU (Directive on Alternative Investment Fund Managers), Directive 2008/48/EC (Directive on credit agreements for consumers), Directive 2002/65/EC (Directive concerning the distance marketing of consumer financial services), Regulation 575/2013 (CRR), Regulation 345/2013 (Regulation on European venture capital funds, EuVECA); Regulation 346/2013 (Regulation on European social entrepreneurship funds, EuSEF).

55 Unleashing the potential of Crowdfunding in the European Union. Communication from the Commission, COM(2014) 172 final, section 1.1. In the US, each Regulation Crowdfunding offering 
The offering of shares to the public in the EU is constrained by prospectus requirements. According to the Prospectus Regulation, "securities shall only be offered to the public in the Union after prior publication of a prospectus". ${ }^{56}$ According to the wording of the Prospectus Regulation, that provision even covers the offering of other securities such as debt instruments to the public. ${ }^{57}$ However, there is an exemption from the prospectus requirements for small offerings of securities. There must be no prospectus requirements where the total consideration in the EU is less than $€ 1$ million over a period of 12 months, ${ }^{58}$ up from $€ 100,000$ under the earlier Prospectus Directive. ${ }^{59}$ Member States must not require a prospectus for smaller offerings but "may require other disclosure requirements at national level to the extent that such requirements do not constitute a disproportionate or unnecessary burden". ${ }^{60}$

The operation of crowdfunding platforms before the adoption of the ECSP Regulation. Building on MiFID II, the European Commission launched its Capital Markets Union (CMU) action plan in September $2015^{61}$ and started work on concrete actions. ${ }^{62}$ The Commission explored the possibilities and risks of crowdfunding in order to find out whether European-level policy action in this field is needed..$^{63}$ In its Green Paper, the Commission briefly mentioned crowdfunding.

As regards the financing of the start-up phase, the CMU action plan mentioned "an increasing variety of non-bank financing options" ranging from "money-lending and donor platforms, businesses trading their invoices, peerto-peer lending, to investment-based crowdfunding or support from business angels". ${ }^{64}$ However, the action plan did not say how they should be developed.

must be exclusively conducted through one online platform. The intermediary operating the platform must be a broker-dealer or a funding portal that is registered with the SEC and FINRA. 56 Article 3(1) of Regulation 2017/1129 (Prospectus Regulation).

57 Article 1(1) of Regulation 2017/1129 (Prospectus Regulation).

58 First subparagraph of Article 1(3) of Regulation 2017/1129 (Prospectus Regulation).

59 Point (e) of Article 3(2) of Directive 2003/71/EC of (Prospectus Directive).

60 Second subparagraph of Article 1(3) of Regulation 2017/1129 (Prospectus Regulation).

61 Action Plan on Building a Capital Markets Union. Communication from the Commission, $\operatorname{COM}(2015) 468$ final.

62 Capital Markets Union - Accelerating Reform. Communication from the Commission, $\operatorname{COM}(2016) 601$ final.

63 Crowdfunding in the EU Capital Markets Union. European Commission, Commission Staff Working Document, SWD(2016) 154 final.

64 Action Plan on Building a Capital Markets Union, section 1.1. 
The 2018 proposal for an ECSP Regulation was part of the European Commission's FinTech Action plan of $2018 .^{65}$ According to this action plan, the proposed Regulation was designed to address the problem that the lack of a common EU framework "hinders the ability of crowdfunding providers to scale-up within the Single Market mainly due to conflicting approaches to national supervision and regulation". Providing an EU-level framework was intended to "ensure the possibility to passport crowdfunding activities throughout the internal market". 66

To complement the ECSP Regulation, the Commission also adopted a proposal for a directive amending MiFID II. ${ }^{67}$ The purpose of the directive was to exclude from the scope of MiFID II crowdfunding service providers that are authorised under the ECSP Regulation.

The operation of crowdfunding platforms after the adoption of the ECSP Regulation. The ECSP Regulation was adopted by the European Parliament in October 2020 and applies from 10 November $2021 .^{68}$ In the light of the ECSP Regulation, there are three main kinds of crowdfunding service providers established in the EU. First, there are crowdfunding service providers that provide services in the home country under the applicable national regulatory regime. Second, there are crowdfunding service providers authorised to provide services under applicable national law where the activities are covered by MiFID II in that Member State. ${ }^{69}$ Third, there are crowdfunding service providers authorised under the ECSP Regulation.

The ECSP Regulation lays down a set of rules for crowdfunding services in the EU. The ECSP Regulation applies to lending-based and investment-based crowdfunding. ${ }^{70}$

The ECSP Regulation applies to all European Crowdfunding Service Providers (ECSP) up to offers of $€ 5$ million, calculated over a period of 12 months per project owner. ${ }^{71}$ The Commission had originally proposed a limit of $€ 1$ million

65 FinTech Action plan: For a more competitive and innovative European financial sector. Communication from the Commission, $\operatorname{COM}(2018) 109$ final.

66 Proposal for a Regulation of the European Parliament and of the Council on European Crowdfunding Service Providers (ECSP) for Business. COM(2018) 113 final, Explanatory memorandum, section 2 .

67 Proposal for a Directive of the European Parliament and of the Council amending Directive 2014/65/EU on markets in financial instruments, $\operatorname{COM(2018)~} 99$ final.

68 Article 51 of Regulation (EU) 2020/1503 (ECSP Regulation).

69 Unleashing the potential of Crowdfunding in the European Union. Communication from the Commission, $\operatorname{COM}(2014) 172$ final, section 1.1.

70 Recital 1 of Regulation (EU) 2020/1503 (ECSP Regulation).

71 Point (c) of Article 1(2) of Regulation (EU) 2020/1503 (ECSP Regulation). 
and the Economic and Monetary Affairs Committee had wanted to expand the scope of the ECSP by increasing the maximum threshold for each crowdfunding offer to $€ 8$ milllion. The threshold of $€ 1$ million is used both in the Prospectus Regulation (with no prospectus requirements where the total consideration in the EU is less than $€ 1$ million over a period of 12 months) $)^{72}$ and the Listing Directive (with a market capitalisation requirement of at least $€ 1$ million for companies that seek official listing). ${ }^{73}$ This makes the threshold of $€ 5$ million significant. $^{74}$

Firms that use the crowdfunding option can be public limited-liability companies. However, to enable small companies or start-ups to use the crowdfunding option, even certain private limited-liability companies can benefit from it. The shares of such private limited-liability companies must be freely transferable. $^{75}$

The ECSP Regulation is designed to protect investors in four main ways relating to authorisation, disclosures, education, and liability.

First, Member States are responsible for authorising and supervising European Crowdfunding Service Providers (ECSPs) under national law. A prospective ECSP needs to request authorisation from the national competent authority of the Member State in which it is established. ${ }^{76}$ Through a notification procedure, an ECSP can provide its services cross-border in other Member States. ${ }^{77}$

Second, the ECSP Regulation regulates disclosures to investors. A key investment information sheet (KIIS) is to be provided to investors for each crowdfund-

72 First subparagraph of Article 1(3) of Regulation 2017/1129 (Prospectus Regulation).

73 Article 43(1) of Directive 2001/34/EC (Listing Directive).

74 According to FESE's position paper, a threshold higher than one million euros was problematic. FESE (2018): “[I]f the ECSP provides crowdfunding offers that are above EUR 1000000 , ECSPs and project owners using their platforms will be subject to the provisions included in the Prospectus Regulation. Indeed, the definition of the 'crowdfunding offer' ... will overlap with the definition of 'an offer of securities to the public' ... thereby putting ECSPs into the scope of both regimes simultaneously. This will drastically reduce the legal clarity for the informational requirements needed for 'crowdfunding offers' issued by ECSPs in the scope of the Crowdfunding Regulation, notably when it is proposed that ECSPs provide lending and equity based crowdfunding services. Furthermore, if such a change were to be agreed, NCAs' flexibility to exempt public offers from prospectus requirements would be undermined. Currently, their flexibility relies on their respective powers to exempt public offer of securities from the obligation to publish a prospectus within their jurisdiction by providing a tailored threshold based on their local ecosystems."

75 Points (m) and (n) of Article 2(1) of Regulation (EU) 2020/1503 (ECSP Regulation).

76 Article 12 of Regulation (EU) 2020/1503 (ECSP Regulation).

77 Article 18 of Regulation (EU) 2020/1503 (ECSP Regulation). 
ing offer. ${ }^{78}$ For example, the KIIS must contain information about the project selection criteria, financial risks, insolvency risks, and charges related to the investment. The key investment information sheet (KIIS) is drawn up by the project owner for each crowdfunding offer, or at platform level.

Third, the ECSP Regulation requires some investor education and nudging to improve investor decision-making. Investors identified as non-sophisticated must be offered more in-depth advice and guidance, including on their ability to bear losses and a warning in case their investment exceeds either $€ 1,000$ or five per cent of their net worth, followed by a pre-contractual reflection period of four calendar days. ${ }^{79}$ The thresholds are very low but do not restrict the size of investment.

Fourth, the ECSP Regulation makes at least the project owner or its administrative, management or supervisory bodies responsible for the information given in a key investment information sheet. ${ }^{80}$ Moreover, the Regulation requires Member States to ensure that civil liability applies. ${ }^{81}$

The ECSP Regulation seems necessary. Common rules can help to increase crowdfunding activity in the EU and reduce barriers to cross-border transactions. Improved access to crowdfunding can help some start-ups at the early stage of development. Moreover, crowdfunding can help to build local ecosystems including advisory services that can benefit start-ups and growth firms in general. Crowdfunding might contribute to a stronger equity culture in the EU.

This said, the ECSP Regulation will not be enough to significantly increase the number of growth firms and companies with publicly-traded shares. This was summed up by FESE in its position on the proposal for a ECSP Regulation: "The capital pooled by crowdfunding platforms remains limited when compared to the capital raised on public markets. In particular, the companies that have the biggest impact on job growth are those at the high end of the funding escalator scale, which means that, even if crowdfunding growth trends continue, this may have only a modest impact on new jobs created in Europe. Furthermore, the visibility ensured by raising capital via crowdfunding is still quite limited and this reflects on the ability of companies to then be able to recruit high profile employees. To fully meet the needs of European companies, with a focus on those that have the highest contribution to job growth, the EU needs to continue work-

78 Article 23 of Regulation (EU) 2020/1503 (ECSP Regulation).

79 Recitals $42-47$ and Articles 21-22 of Regulation (EU) 2020/1503 (ECSP Regulation).

80 Article 23(9) of Regulation (EU) 2020/1503 (ECSP Regulation).

81 Article 23(10) of Regulation (EU) 2020/1503 (ECSP Regulation). 
ing on a comprehensive strategy on how to boost equity financing at all stages of the funding escalator." 82

The provisions of the ECSP Regulation on investor protection are necessary to guard against the loss of public confidence in crowdfunding and capital markets in general. ${ }^{83}$ However, no such provisions will change the high-risk nature of equity crowdfunding.

Conclusion. The regulation of crowdfunding has been very fragmented in the EU in the past. EU securities law generally is based on a piece-meal approach. The core pieces of EU law include MiFID II and the Prospectus Regulation. EU law is complemented by Member States' national laws. Combined with the principle of subsidiarity, the existence of national regulation has made it more difficult to adopt a common regulatory framework for crowdfunding. The ECSP Regulation creates a regulatory framework for cross-border investment crowdfunding.

\subsection{The Regulation of Securities-Based Crowdfunding in the US}

The starting point of the regulation of securities-based crowdfunding in the US is the very wide scope and expansive interpretation of the Securities Act of 1933 and the Securities Exchange Act of 1934.

The Securities Act bans offers to sell or buy securities without a registration statement. ${ }^{84}$ Anyone offering securities to the public must first prepare a registration statement with the SEC and make that statement available "under such regulations as the [SEC] may prescribe". ${ }^{55}$ Putting information about an issue of securities up on a website falls within the scope of the general solicitation ban under the 1933 Act. $^{86}$

Anyone acting as a broker must be registered under Section 15 of the Securities Exchange Act. Any person who operates a website offering securities for sale on behalf of an issuer falls within the expansive definition of broker in the 1934 Act. $^{87}$

\footnotetext{
82 FESE (2018).

83 Ibid.

84 Section 5 of the Securities Act of 1933.

85 Section 6(d) of the Securities Act of 1933.

86 See Kitch EW (2014) p 888; Heminway JM (2017) p 196.

87 Kitch EW (2014) p 888.
} 
The Securities Act of 1933 used to hamper the funding of early-stage ventures. Since registration is expensive and time-consuming, smaller growth firms needed to rely on an exemption to raise capital. ${ }^{88}$ For example, under Rule 506 of Regulation D, they could seek funding from "accredited investors" such as wealthy individuals through private placements and without going public. ${ }^{89}$ However, they were not allowed to advertise the sale of their stock in public. The ban on general solicitation prevented startups from promoting their companies and seeking investors via online platforms. ${ }^{90}$

The Jumpstart Our Business Startups (JOBS) Act of 2012 made it easier for companies to raise capital privately, stay private longer, or go public:

- Title I of the JOBS Act exempted "emerging growth companies"91 from certain disclosure duties and other obligations.

- Title IV of the JOBS Act directed the SEC to adopt rules exempting from the registration requirements of the Securities Act offerings of up to $\$ 50$ million of securities annually. ${ }^{92}$

- $\quad$ Title II of the JOBS Act restricted the scope of the general solicitation ban. It removed the ban on general solicitation provided that only accredited investors are solicited and there are reasonable steps to verify that the purchasers are accredited investors. ${ }^{93}$ In other words, Title II facilitated online investing subject to certain constraints. Title II resembles angel investing and is regarded as a success. ${ }^{94}$

88 For US law before the JOBS Act of 2012, see Burkett E (2011). Williamson JJ (2013) p 2071.

89 Williamson JJ (2013) p 2072.

90 See, for example, Catalini C, Fazio C, Murray F (2016) p 4.

91 Section 101(a) of the JOBS Act added Section 2(a)(19) to the Securities Act of 1933 as follows: “(19) The term 'emerging growth company' means an issuer that had total annual gross revenues of less than $\$ 1,000,000,000$...” The thresholds are indexed for inflation. Section 101(b) of the JOBS Act added a similar Section 3(a)(80) to the Securities Exchange Act of 1934.

92 Section 401 of the JOBS Act added Section 3(b)(2) to the Securities Act of 1933. The SEC adopted the necessary rules in Regulation A+ that expanded the earlier Regulation A. SEC Release Nos. 33-9741; 34-74578; 39-2501 (Amendments for Small and Additional Issues Exemptions under the Securities Act) (Regulation A).

93 Section 201(a) of the JOBS Act; SEC Release No. 33-9415; No. 34-69959 (September 23, 2013) (Eliminating the Prohibition Against General Solicitation and General Advertising in Rule 506 and Rule 144A Offerings).

94 Ibrahim DM (2015) pp 565 and 582: "Title II platforms are simply taking advantage of the Internet to reduce the transaction costs of traditional angel and VC operations and add passive angels to their networks at a low cost ... Title II sites are replicating angel risk-reduction mechanisms in an online setting." 
- $\quad$ Title III of the JOBS Act is also known as the CROWDFUND Act. ${ }^{95}$ It has been called a paradigm shift. ${ }^{96}$ Title III opened up online investing even for unaccredited investors such as retail investors. Title III achieved this by adding an exemption from registration for certain crowdfunding transactions ${ }^{97}$ and by permitting equity crowdfunding. ${ }^{98}$ In particular, "emerging growth companies" were permitted to engage in crowdfunding while remaining exempt from registration requirements. ${ }^{99}$

Title III created a special exemption from the requirements of the Securities Acts. To implement the exemption, the SEC adopted Regulation Crowdfunding in 2015..$^{100}$

Regulation Crowdfunding prescribed rules governing the offer and sale of securities under the new Section 4(a)(6) of the Securities Act of 1933 and provided a framework for the regulation of registered funding portals and brokers that issuers are required to use as intermediaries in the offer and sale of securities in reliance on Section 4(a)(6).

Regulation Crowdfunding provided a regulatory framework for securities crowdfunding by (i) permitting individuals to invest in the securities of an issuer, subject to certain investment limitations, (ii) capping the funds that may be raised by an issuer under crowdfunding at $\$ 1$ million (with later inflation adjustments) in a 12-month period, (iii) requiring issuers to disclose certain information about their business and offerings, including in an offering statement and annual reports, and (iv) providing a regulatory framework for intermediaries that operate the crowdfunding platform or otherwise facilitate the crowdfunding. Such intermediaries include registered brokers and funding portals.

Regulation Crowdfunding did not limit the scope of other exemptions. The issuer is permitted to rely on other securities exemptions such as Regulation D as well. However, the Title III and Regulation Crowdfunding exemption is limited and includes complex disclosure and filing provisions. ${ }^{101}$

95 The Capital Raising Online While Deterring Fraud and Unethical Non-Disclosure Act.

96 Ibrahim DM (2015) p 587.

97 Section 302 of the JOBS Act added Section 4(a)(6) to the Securities Act of 1933.

98 SEC Release No. 33-9974 (Oct. 30, 2015) (Regulation Crowdfunding). The release adopting inflation adjustments to the dollar amount thresholds in Regulation Crowdfunding is SEC Release No. 33-10332 (March 31, 2017).

99 Williamson JJ (2013) p 2074.

100 See Regulation Crowdfunding: A Small Entity Compliance Guide for Issuers (May 13, 2016) prepared by the staff of the SEC; Heminway JM (2017) pp 197-198.

101 See Regulation Crowdfunding: A Small Entity Compliance Guide for Issuers (May 13, 2016) prepared by the staff of the SEC; Kitch EW (2014) pp 891-892. 
The Title III and Regulation Crowdfunding exemption is not available to all companies. The exemption is only available to US companies. Non-US companies are not eligible to use the exemption. Certain US companies are excluded from the exemption. For example, Title III prohibited "investment companies" from operating under the Act, preventing companies that make investments for others from offering mutual fund-type crowdfunding products. ${ }^{102}$

Each Regulation Crowdfunding offering must be exclusively conducted through one online platform. The issuer cannot conduct a crowdfunded offering on its own. The intermediary operating the platform must be a broker-dealer or a funding portal registered with the SEC and FINRA. A website operator could thus satisfy its obligation to register as a broker under Section 15 of the Securities Exchange Act by qualifying as a "funding portal". ${ }^{103}$

A funding portal is not allowed to: offer investment advice or recommendations; solicit purchases, sales or offers to buy the securities on its platform; compensate employees, agents or other persons for solicitation or based on the sale of securities displayed on its platform; hold, manage, possess or otherwise handle investor funds or securities; or engage in such other activities as the SEC, by rule, determines appropriate.

Since a funding portal cannot handle investor funds, it must direct investors to transmit their funds directly to a qualified third party, which may be a registered broker-dealer or qualifying bank or credit union. A funding portal may nevertheless engage in back-office or other administrative functions other than on the platform.

Congress narrowed the scope of the exemption by limitations on both the amount of securities a single issuer could sell and the amount of securities that could be sold to a single investor under the crowdfunding exemption. An exempted offering must be for less than $\$ 1$ million during any twelve-month period (with later inflation adjustments). ${ }^{104}$ There is an investment limit depending on the annual income and net worth of the individual investor. No buyer may

102 Section 302(b) of the JOBS Act; Williamson JJ (2013) p 2075.

103 Kitch EW (2014) p 892: "The newly proposed regulation on funding portals requires that they become members of the Financial Industry Regulatory Authority, something that few operators of websites will find it feasible to do."

104 After April 5, 2017 updates to reflect inflation adjustments to the dollar amount thresholds) a company issuing securities in reliance on Regulation Crowdfunding was permitted to raise a maximum aggregate amount of $\$ 1,070,000$ in a 12-month period. 
purchase an amount in excess of 10 percent of his or her annual income or net worth. $^{105}$

Neither the JOBS Act nor Regulation Crowdfunding included explicit restrictions on the types of securities that issuers could sell in crowdfunding offerings. To foster market development, the SEC declined to narrow the list of instruments that companies could offer crowdfunding investors. As a result, "startups looking to raise capital through crowdfunding have had free rein to choose whichever instruments they believe best fit their needs". ${ }^{106}$

The JOBS Act and Regulation Crowdfunding restrict resales. Resales of securities acquired in an offering conducted using the crowdfunding exemption are prohibited for a one-year period following the date on which the securities are purchased, with certain exceptions. ${ }^{107}$ The resale restrictions are clarified by Rule 501 of Regulation Crowdfunding. The resale restrictions have been regarded as controversial. Resale restrictions may hamper the development of a liquid trading market for the affected securities. ${ }^{108}$

A crowdfunding intermediary is permitted to have a financial interest in an issuer on its platform under certain circumstances. This is the case where the securities are a form of compensation and of the same class as the offered securities: The intermediary receives the financial interest from the issuer as compensation in connection with the crowdfunding transaction, and the financial interest consists of securities of the same class and having the same terms, conditions and rights as those being offered in the crowdfunding transaction.

A crowdfunding intermediary has duties to protect investors from fraud. First, the intermediary must have a reasonable basis for believing that an issuer complies with Section 4A(b) of the Securities Act of 1933 and has established means to keep accurate records of its security holders. Second, an intermediary must deny access to its platform to an issuer if the intermediary has a reasonable basis for believing that the issuer is a "bad actor", or has a reasonable basis for believing that the issuer or the offering presents the potential for fraud or otherwise raises concerns about investor protection. Third, an intermediary must deny access to its platform if it reasonably believes that it is unable to adequately or effectively assess the fraud risk connected to the issuer or its proposed offering.

A crowdfunding intermediary must disclose information to protect investors. For example, an intermediary must:

105 Kitch EW (2014) p 892; Regulation Crowdfunding: A Small Entity Compliance Guide for Issuers (May 13, 2016) prepared by the staff of the SEC.

106 Green JM, Coyle JF (2016) pp 170 - 171.

107 Heminway JM (2017) p 198.

108 Ibid., pp 200-202. 
- provide investors with transaction and educational materials, including disclosures relating to risk and resale restrictions;

- disclose on its platform the compensation and promotional activities of any promoter, founder or employee of an issuer;

- disclose the manner in which the intermediary is compensated for the crowdfunded transaction;

- make available information required to be provided by the issuer, including an offering statement and progress updates;

- have a reasonable basis that the investor satisfies the investment limitations under Regulation Crowdfunding and obtain certain investor qualification materials and representations from the investor;

- provide communication channels on its platform so that potential investors can communicate with each other and with representatives of the issuer; and

- abide by certain rules relating to investment notices, completion of offerings, cancellations and reconfirmations.

Conclusion. The JOBS Act of 2012 and Regulation Crowdfunding facilitated the operation of crowdfunding platforms and made equity crowdfunding legal. Retail investors are protected by disclosures, caps, and a one one-year holding requirement for crowdfunded securities.

For issuers, Regulation Crowdfunding reduced the costs of regulatory compliance in securities offerings. However, compliance costs remain higher compared with a traditional private placement under Regulation D. Generally, Congress regards the JOBS Act of 2012 as an example of good regulation that eases regulatory burdens, increases regulatory certainty, and encourages entrepreneurs and startups. ${ }^{109}$

\subsection{Some Crowdfunding Practices}

The crowdfunding market has adapted to regulation and developed crowdfunding instruments and standard-form contracts. ${ }^{110}$ Crowdfunding practices should be taken into account when choosing design principles for the regulation of crowdfunding (section 7.5) and could be taken into account when developing de-

109 The 2017 Joint Economic Report (115 ${ }^{\text {th }}$ Congress), Chapter 6, pp 122-137, at p 133. 110 Williamson JJ (2013) p 2073; Wroldsen JS (2013) p 627; Hornuf L, Klöhn L, Schilling T (2018) on German crowdfunding practices. 
sign principles for the proposed microexchange (Chapter 8). We can have a look at some crowdfunding practices.

Many core services on crowdfunding platforms. The operators of crowdfunding platforms obviously play a central role. ${ }^{111}$ The core service on a crowdfunding platform consists of linking projects and contributors. There are even other core services necessary to make a two-sided digital platform work. In particular, rational choice can be helped by curation.

The services of the operators of crowdfunding platforms have been described as follows: "They act as gatekeepers because they decide which startups can run crowdfunding campaigns on their platforms ... Furthermore, these platforms are information intermediaries because they evaluate start-ups, stipulate what information they have to provide to investors, and channel communications between investors and businesses in an investor-relations portal. Finally, they are drafters of contracts because they develop the contracts that are concluded between investors and businesses." "112

Users may thus choose the services of crowdfunding platforms for many reasons. According to Gabison, platforms remove some of the stigma associated with asking friends and family for money, signal the legitimacy of the project, reassure contributors, and give creators a place to publicise their projects and reach a broader network. ${ }^{113}$ There has been little detected fraud in crowdfunding. ${ }^{114}$

Standard form contracts. All products offered on the crowdfunding platform are designed by the platform operator. Moreover, crowdfunding websites customarily provide standard form contracts to be used by issuers and investors. Since standard form contracts can reduce transaction costs and legal risk, they can contribute to the fast convergence of practices. For example, the platform operator's standard contracts are used for every offering on German platforms. ${ }^{115}$

In the US, contracts and instruments have been influenced by incubator, angel, and venture capital practices. ${ }^{116}$ Issuers were given plenty of discretion in the JOBS Act of 2012. The JOBS Act and the SEC's regulatory practices fostered market development by keeping the list of instruments that companies could

111 Wroldsen JS (2017); Hornuf L, Klöhn L, Schilling T (2018) p 519.

112 Hornuf L, Klöhn L, Schilling T (2018) pp 518-519.

113 Gabison GA (2015) pp 363-365.

114 Cumming DJ, Hornuf L, Karami M, Schweizer D (2016).

115 Hornuf L, Klöhn L, Schilling T (2018) p 519.

116 For innovation, see Coyle JF, Green JM (2014). 
offer to crowdfunding investors open. ${ }^{117}$ This led to the standardisation of contract practices and investor protection mainly through social media. From a European perspective, reliance on social media and "the wisdom of the crowd" has been described as "similar to libertarian theory, which holds that markets are most effective without any regulatory intervention". ${ }^{118}$

US crowdfunding practices were summed up by Wroldsen in a 2017 article. ${ }^{119}$ First, the rewards-based model of crowdfunding (à la Kickstarter) strongly influences crowdfunding investment practices. Crowdfunding investors may find more leverage and protection through the power of social media than through discrete contractual provisions. Second, crowdfunding intermediaries play an influential role in crowdfunding investment practices, particularly in the area of standardised investment contracts. Third, equity securities are more common than debt securities. Fourth, novel investment contracts such as the SAFE and the KISS are used in crowdfunding. The SAFE and the KISS were originally designed for the funding of early-stage start-ups. SAFE is the acrynom for "Simple Agreement for Future Equity" originally developed by Y Combinator. KISS means the "Keep It Simple Security" developed by 500 Startups. ${ }^{120}$

Angel funding practices as a model for contractual innovation in the US. The regulation of equity crowdfunding in the US leaves room for contractual innovation. In practice, contractual innovation often means the reception of angel and venture capital practices in the crowdfunding context.

Issuers tend to offer stock or convertible securities to prospective crowdfunding investors. In the US, most of the convertible securities were found to be SAFEs in a 2016 study (section 5.3). ${ }^{121}$ SAFEs were used by two different types of issuers: tech startups that were potentially attractive to venture capital investors, and non-tech startups with business models that were less likely to attract venture capital. ${ }^{122}$

However, the SAFE may not be an appropriate instrument for crowdfunding investments. A SAFE will prove valuable to the holder if, and only if, the company that issues it raises a subsequent round of financing, is sold, or goes public. Start-ups that use crowdfunding customarily are start-ups that cannot raise ven-

117 Green JM, Coyle JF (2016) pp 170 - 171.

118 Zetzsche DA, Preiner C (2018) p 225.

119 Wroldsen JS (2017).

120 See Coyle JF, Green JM (2014) pp 168-171. Critically on the use of the SAFE in crowdfunding Green JM, Coyle JF (2016).

121 Green JM, Coyle JF (2016) pp 174-176.

122 Ibid. 
ture capital and are unlikely to go public in the future. ${ }^{123}$ (One may ask whether the use of SAFEs should be complemented by a new kind of secondary market (Chapter 8).)

Venture capital practices as a model for contractual innovation in Germany. In Germany, contractual practices are influenced by the fact that transferring shares of a limited-liability company $(\mathrm{GmbH})$ requires the involvement of a notary, which is too expensive in the context of equity crowdfunding. ${ }^{124}$ This has contributed to the adoption of venture capital contract practices in German equity crowdfunding. ${ }^{125}$ Crowd investors have also been asked to pay higher prices if they receive more cash flow and exit rights. However, it has turned out that these rights have no meaningful economic impact, because crowd investors are passive investors whose control rights either are ineffective or not exercised. ${ }^{126}$

Future access to venture capital as a constraint on contractual protection. Crowdfunding contracts can hamper the start-up's access to venture capital funding in later funding rounds. Venture capital investors reject most investment proposals. The more complicated the proposed investment, the more likely it is to get rejected.

One of the core differerences between crowdfunding and venture capital contracts is that crowdfunding contracts customarily are standardised, whereas traditional venture capital terms are negotiated individually for each project. This can be the cause of potential conflicts between the two contractual frameworks. $^{127}$

Where crowdfunding investors are protected by contractual clauses and company law rights that venture capital investors want for themselves, the start-up's investment proposal is less likely to be accepted.

In a 2019 study, Moedl found deal-breakers: "[W]e find empirical evidence that, e.g., an inflated capitalization table owing to crowd investors holding direct securities in a company, redemption and voting rights by the crowd, as well as the non-existence of a drag-along clause, lead venture capitalists and business angels to refrain from an investment in an otherwise attractive but such-funded

\section{Ibid.}

$124 \S 15$ GmbHG; Hornuf L, Schilling T, Schwienbacher A (2019).

125 Hornuf L, Schilling T, Schwienbacher A (2019): “This, however, is a specificity of the German market, so contract structure may not be generalized to other countries. However, it shows that in a regulatory environment that allows wide contractual freedom, contracts used turn out to be similar to venture capital deals that separate cash flow rights from control rights."

126 Ibid.

127 Moedl M (2019) p 28. 
start-up firm." 128 In practice, this means that "contractual frictions play a decisive role in whether entrepreneurs can combine crowd-based means of funding with traditional forms of venture financing". ${ }^{129}$

Moedl illustrated how these deal-breakers work with the case of Smarchive, a German start-up. In the absence of venture capital funding, Smarchive raised $€ 100,000$ from 144 crowd investors in exchange for an aggregated six percent stake in equity. Three months later, Smarchive received a much larger offer from a venture capital fund. The offer was conditional on termination or remodeling of the crowd investment. This required the consent of each and every crowd investor under German law. ${ }^{130}$

From this, we can draw three conclusions for crowdfunding practice. First, the requirements of later-stage funding can make it difficult for the start-up and the founders to protect investors in early-stage funding rounds. Second, the terms of crowdfunding investment contracts cannot be the primary source of investor protection. Instead, crowdfunding investors may need to rely on laws, social media, the wisdom of crowds, and their collective voice. ${ }^{131}$ Third, if crowdfunding investors are protected by contractual clauses, a special-purpose vehicle (SPV) and contracts on collective decision-making can - in countries where it is legal - be used to make it easier for the start-up to obtain shareholder consent in the event that it seeks more funding in later funding rounds. ${ }^{132}$

Quality signals in social media. In the absence of effective legal protection and a secondary market, contributors that seek to invest in high-quality projects rely on private quality signals.

According to a study, contributors tend to respond to signals about the quality of the project, regardless of their expectations for financial return. Social media plays an important role: "High quality projects attract backers who may promote the project to other potential backers, or external media, thus increasing the draw of the project. Crowdfunding is built around this social concept, which is incorporated into most funding sites ... [and] protects the interests of investors--it seeks to prevent that the company is drastically undercapitalized ..."133 At the same time, fraud is rare.

128 Ibid., p 1. See also ibid., p 4.

129 Ibid., p 1.

130 Ibid., p 3.

131 Wroldsen JS (2017).

132 Hornuf L, Klöhn L, Schilling T (2018) p 518; Gabison GA (2015) pp 365-366 footnote 28. For legal constraints in the US, see section 302(b) of the JOBS Act of 2012 and section 3 of the Investment Company Act of 1940.

133 Mollick E (2014) p 6. 
In the US, Regulation Crowdfunding requires a crowdfunding intermediary to provide communication channels on its platform so that potential investors can communicate with each other and with representatives of the issuer. ${ }^{134}$ In other words, Regulation Crowdfunding facilitates the function of social media as a monitoring and control mechanism.

Attainment of funding targets and the use of funds. The management of payments can keep crowdfunding offerings serious and prevent fraud. The platform customarily is involved in the execution of payments. ${ }^{135}$ Risk is reduced in two ways. The first relates to the attainment of funding targets and the use of funds. The second relates to the holding of funds.

Funding targets are taken into account in platform design one way or another. The funding process is double-layered. After contributors have decided to finance a project and offered their contributions, the funds either will or will not be distributed to the project. Whether they will be distributed depends on the funding targets and the way funding targets are taken into account.

It is customary to choose between the flexible funding model and the all-ornothing approach. Under the flexible funding model, the company receives the raised funds even when targets are not reached. ${ }^{136}$ The all-or-nothing model requires a critical mass to believe in the project before it is funded. Platforms only divest the funds collected to the campaign creator if the target is reached. ${ }^{137}$

According to Hofmann, the all-or-nothing approach "only permits funding to be provided to companies when the aggregate amount raised meets the predetermined targets" and "is more common because it protects the interests of investors--it seeks to prevent that the company is drastically undercapitalized and thereby exposes the investors to a particularly high risk of default”. ${ }^{138}$

In the US, Regulation Crowdfunding sets out how to deal with targets. An issuer must disclose the target, the deadline, and the all-or-nothing approach: "The target offering amount and the deadline to reach the target offering amount, including a statement that if the sum of the investment commitments does not equal or exceed the target offering amount at the offering deadline, no securities will be sold in the offering, investment commitments will be cancelled and committed funds will be returned ...” An issuer must also disclose what will happen when the target is exceeded: "Whether the issuer will accept investments in excess of the target offering amount and, if so, the maximum

134 Regulation Crowdfunding, §227.303(c).

135 Hofmann C (2018) p 226.

136 Ibid., p 226.

137 Gabison GA (2015) pp 363-365.

138 Hofmann C (2018) p 226. 
amount that the issuer will accept and how oversubscriptions will be allocated, such as on a pro-rata, first come-first served, or other basis ..."139

The holding of customer funds. The holding of customer funds is a regulated activity in financial services. Whether the platform operator may hold investor funds can depend on its authorisation or registration and its regulatory compliance obligations.

In the EU, the scope of the MiFID II authorisation requirement can depend on the holding of customer funds. ${ }^{140}$ Moreover, the "[s]afekeeping and administration of financial instruments for the account of clients, including custodianship and related services such as cash/collateral management and excluding maintaining securities accounts at the top tier level" is regarded as an "ancillary service" under Section B of Annex I to MiFID II. The revised Payment Services Directive (PSD2) permits even non-banks to provide payment services, ${ }^{141}$ but neither account information service providers (AISPs) nor payment initiation service providers (PISPs) are permitted to hold customers funds. They will, therefore, need to co-operate with investment firms or banks. ${ }^{142}$

In the US, a funding portal must not "hold, manage, possess, or otherwise handle investor funds or securities". For this reason, it must direct investors to transmit their funds directly to a qualified third party, which may be a registered broker-dealer or qualifying bank or credit union. In any case, where the platform is permitted to hold customer funds, the holding of client funds is a regulated activity to reduce investors' counterparty risk. ${ }^{143}$

In some jurisdictions, the platform or a third party can hold title to securities as a fiduciary of investors. Investors can even invest in securities issued by a holding company that in turn invests in the crowdfunding project (see below). ${ }^{144}$

Direct equity investments, an SPV or pooling. In principle, equity crowdfunding investments could be direct equity investments (in the shares of the issuer), investments in the shares of an intermediate vehicle (such as a holding company, a special-purpose vehicle, or a fund), or based on nominee structures (with the operator of the platform or a third party as a fiduciary).

US securities law restricts the pooling of retail investors' investments in crowdfunding. Section 302(a) of the JOBS Act provides for a crowdfunding exemption from registration requirements for "emerging companies" and allows

139 Regulation Crowdfunding, §227.201.

140 Point (a) of Article 3(1) of Directive 2014/65/EU (MiFID II).

141 Points (3) and (4) of Article 4 of Directive 2015/2366/EU (PSD2).

142 Recitals 31 and 35 of PSD2.

143 Hofmann C (2018) p 226.

144 Ibid., pp 226-227. 
emerging companies to raise up to a total of $\$ 1$ million (with later adjustments for inflation) annually from individuals who do not meet the "accredited investor" threshold. ${ }^{145}$ However, section 302(b) of the JOBS Act prohibits "investment companies" from operating under the Act, preventing companies that make investments for others from offering mutual fund-type products. The exclusion of "investment companies" makes it more difficult for retail investors to pool their crowdfunding investments and diversify their holdings. ${ }^{146}$

In Europe, investment contracts are usually concluded directly between investors and start-ups, but sometimes a special purpose vehicle (SPV) may function as an intermediary for matching investments with the start-up. ${ }^{147}$ This can be illustrated with the cases of Symbid in the Netherlands and Companisto in Germany.

Symbid was described by Gabison as follows: "Symbid, a major equity-based crowdfunding platform, organizes the investors of a successful crowdfunding investment round into a single purpose vehicle ... The investor syndicate will be heard as a group and stand behind one powerful vote representing the entire amount of the equity offered in the fundraising campaign; in other words, the whole investor syndicate gets one vote. This ensures that the investors' voices are heard, but it also keeps the business attractive to future rounds of financing, which is the key to investors' ultimate goal of liquidity."148

Companisto explained how the pooling of investments worked in 2019 in its FAQs: "Since most startups regularly need additional capital for their future growth, Companisto contracts are optimized for follow-up financing by venture capital companies. This is to the advantage of both the startup and the company. Only startups that continue to have the opportunity to raise venture capital can grow and be successful in the long term. This requires contractually regulated coordination processes. To ensure that these can be carried out smoothly, the Companists' investments are pooled, i.e. bundled. The startup or venture capital company thus has a central contact for follow-up financing rounds. Without this pooling, a startup would no longer be interesting for venture capital companies who do not want to deal with a large number of contacts.”149

145 See, for example, Williamson JJ (2013) p 2074.

146 Ibid., p 2075.

147 Hornuf L, Klöhn L, Schilling T (2018) pp 518-519. See Gabison GA (2015) pp 365-366 footnote 28 mentioning that Seedrs in the UK, Symbid in the Netherlands, and MyMicrolnvest in Belgium offer such intermediary services.

148 Gabison GA (2015) pp 365-366 footnote 28.

149 Companisto website. 
In Singapore, it is customary to use nominee accounts for the bundling of funds. In this case, a third party holds the legal title to the company's equity rights as a fiduciary on behalf of the investors who are the beneficial owners. The platform often has this function. ${ }^{150}$

\subsection{Some Design Principles for the Regulation of Equity Crowdfunding Marketplaces}

The crowdfunding market is regulated one way or another. ${ }^{151}$ How should equity crowdfunding be regulated? When drafting design principles for the regulation of crowdfunding, we can take into account the characteristics of crowdfunding and crowdfunding practices (section 7.4).

On one hand, crowdfunding can bring benefits to start-ups. First, it can complement traditional forms of start-up funding. For example, a start-up may for some reason or another have no access to angel funding or venture capital. ${ }^{152}$ Second, it might appeal to start-ups that need cash but not the customary ancillary services of venture capital investors. ${ }^{153}$ Third, the operators of crowdfunding platforms can be start-ups or growth firms themselves. Competition between many platform operators can bring innovation and new business models to start-up funding.

On the other, there is a risk of adverse selection and the emergence of a market for lemons, ${ }^{154}$ the potential rewards for investors can be limited, ${ }^{155}$ and their risk exposure is increased by the lack of a secondary market.

150 Hofmann C (2018) pp 226-227.

151 See, for example, Wroldsen JS (2013) pp 632-634; Gabison GA (2015) p 362.

152 See Ibrahim DM (2015) pp 591-592; Hofmann C (2018) p 229. For the case of Smarchive, see Moedl M (2019) p 3.

153 Ibrahim DM (2015) p 589.

154 There is a similar problem when lawyers take equity instead of cash for their services. Coyle JF, Green JM (2017) pp 1427-1428: "Just as Groucho Marx once observed that he would never want to belong to a club that would admit him as a member, one North Carolina lawyer pointed out that those clients who were willing to give their lawyers an equity stake were-as a general matter-not the ones in which the law firms wanted to invest."

155 Hofmann C (2018) p 229: "[I]t is questionable whether non-professional investors should take on disproportionately high risks in exchange for the prospect of rather modest returns." Ibrahim DM (2015) pp 591-592: "Title III is unlikely to replace traditional entrepreneurial finance or Title II. Startups have historically preferred to use Rule 506 to raise funds from accredited investors only, and there is unlikely to be a sea change toward seeking out unaccredited investors." 
Adverse selection may be triggered by the high-risk nature of early-stage start-ups ${ }^{156}$ and the tendency of high-quality start-ups to raise angel funding and venture capital. Start-ups that choose crowdfunding may be of lower quality. ${ }^{157}$ If this is what investors believe, the crowdfunding market can become a market for lemons.

Crowdfunding projects cannot have the same upside for investors as projects that raise angel funding or venture capital. Crowdfunding that is based on donations or rewards is a form of consumption rather than investment. Equity crowdfunding is coupled with a higher risk than loan-based crowdfunding, but the higher risk does not mean higher returns.

Moreover, the risk exposure of investors is increased by the lack of a secondary market. The lack of a secondary market can hamper the growth of the primary crowdfunding market. ${ }^{158}$

In any case, rulemakers need design principles for the regulation of crowdfunding platforms and offerings. We can have a look at some potential design principles.

Focus on start-ups. Regulators should focus on the interests of start-ups, because crowdfunding cannot provide financial security to contributors.

When crowdfunding is not a form of contributors' consumption, it is a highrisk investment. Regulation can do little to change the high-risk nature of crowdfunding. Regulators should therefore focus on the growth of start-ups and make it easier for start-ups to take steps on the funding path. ${ }^{159}$

Retail investors should be protected against abuses and fraud. There should be a light disclosure regime to prevent fraud and facilitate rational decision-mak-

156 Gilson RJ (2003) p 1076; Gabison GA (2015) pp 369-370; Ibrahim DM (2015) p 573: “As Ronald Gilson was the first to explain, early-stage startups present extreme levels of uncertainty, information asymmetry, and agency costs."

157 See, for example, Catalini C, Fazio C, Murray F (2016) p 7 on adverse selection and moral hazard problems; Gabison GA (2015) pp 369-370 on fraud, incompetence, and lack of exit strategies.

158 Gabison GA (2015) pp 368-370.

159 Compare Hofmann C (2018) pp 230 -231: "Regulators face various challenges. Companies show little willingness for disclosure and platforms are no natural guardians of investors' interests. Additionally, non-institutional investors have barely any ways to acquire all relevant information about the envisaged investment, to monitor the recipients of their funding or to mimic sophisticated investors. Based on these findings, the regulatory focus of crowdfunding must be, and actually is, on the investment risk to which retail investors are subjected. The regulatory dilemma consists in finding the right balance between supporting a new and positively viewed funding model and providing the right level of investor protection." 
ing. ${ }^{160}$ Overregulation with a seemingly high level of investor protection might both mislead investors into believing that crowdfunding is an investment that can provide financial security and hamper the growth of start-ups.

Use regulatory dualism. It is fundamental to address the scope of the general regulatory regime for securities exchanges and securities offerings. Should crowdfunding platforms and offerings fall within the scope of the general regulatory regime or be exempted? ${ }^{161}$ It seems that they should be exempted. This is indeed the case in the US and the EU.

Crowdfunding would not be commercially viable without exemptions from the general regulatory regime, because start-ups would not be able to cope with the high cost of regulatory compliance. Crowdfunding would not exist without exemptions.

Moreover, even where start-ups could cope with the high cost of regulatory compliance, the intended effects of the regulatory regime would be counterproductive. The general regulatory regime is designed to increase trust. The admission of securities to trading on a regulated market signals the high quality of the securities and the issuer - or at least the absence of circumstances that customarily are associated with securities and issuers that are unsuitable for retail investors. If crowdfunding issuers and investments fall within the scope of the general regulatory regime and inherently low-quality equity investments are offered to retail investors, investors' trust is abused. The inevitable failure of many high-risk start-up projects might then compromise the perceived quality of higher-quality issuers and the regulatory regime in general. For this reason, the better alternative seems to be to exempt equity crowdfunding offerings from the scope of the general regulatory regime.

In the light of the potentially low quality of crowdfunding offerings and the high-risk nature of early-stage equity investments, crowdfunding platforms play an important role. Crowdfunding platforms should be used as a filter and screening mechanism to ensure that start-ups and projects fulfil minimum requirements, and to reduce the risk of abuse and fraud. For this reason, there should be a regulatory regime for crowdfunding platforms. Regulatory dualism (section 6.3.12) can help.

Increase the variety and quality of crowdfunding platforms. The regulation of crowdfunding should seek to increase the variety of crowdfunding platforms and

160 In the US, Regulation Crowdfunding, §227.201.

161 Compare Gabison GA (2015) p 362: "Faced with these new types of IPO, some countries choose one of three positions: ignore this phenomenon and retrofit the applicable existing regulations; reaffirm which regulations apply; or create new regulations to deal with crowdfunding." 
improve their quality. There can be a trade-off between variety and quality. The regulatory regime should nevertheless try to achieve both through regulatory dualism.

To increase variety and quality, regulators need to foster innovation and competition. It should be possible even for new players to operate a crowdfunding platform. Where regulators prefer to use the general regulatory regime, apply the one-size-fits-all-principle, or aim for a level playing field for all exchange or platform operators, crowdfunding platforms may end up being operated by large established financial firms whose core competences include regulatory compliance. ${ }^{162}$ There should be a lighter regulatory approach to enable the market to develop.

To reduce abuse, there should be an authorisation or registration requirement for the operators of investment crowdfunding platforms. Fraud risk can be reduced by regulating the holding of customer funds. In practice, fraud has been rare in crowdfunding. ${ }^{163}$

In the US, Title II and Title III of the JOBS Act are examples of regulatory dualism combined with a registration obligation. The crowdfunding website must be operated by a licensed securities broker or a registered funding portal. In other words, a website operator could satisfy its obligation to register as a broker under Section 15 of the Securities Exchange Act by qualifying as a "funding portal". ${ }^{164}$ The value of Title III platforms is seen to lie in their contribution to market innovation: "Equity crowdfunding platforms can also play a key role in shaping the future of Title III markets beyond the SEC rules. Platform rules, selfregulation, technical features and cultural norms will also shape how attractive online platforms ultimately become to high-growth startups and everyday investors. By experimenting with new market design rules, data streams (e.g. integration with verifiable growth metrics) and milestone-based funding, Title III platforms could substantially improve the quality and type of startups they are able to attract."165

In the EU, the Regulation on European Crowdfunding Service Providers (ECSP) for Business exempts ECSPs from obligations under MiFID II. ECSPs cannot be authorised under MiFID II. ${ }^{166}$

162 See Kitch EW (2014) p 893; Burkett E (2011) p 92.

163 Mollick E (2014).

164 Kitch EW (2014) p 892: “The newly proposed regulation on funding portals requires that they become members of the Financial Industry Regulatory Authority, something that few operators of websites will find it feasible to do."

165 Catalini C, Fazio C, Murray F (2016) p 8.

166 See recitals 10 and 75 of Regulation (EU) 2020/1503 (ECSP Regulation). 
Rely on laws of general application, private quality signals, reputational intermediaries, social media, and the wisdom of crowds. Retail investors should not be protected by high admission and prospectus requirements. Instead, retail investors should be protected by laws of general application, private quality signals, reputational intermediaries, social media, and the wisdom of crowds.

Crowdfunding platforms are two-sided platforms. To succeed in the long run, they should provide value to both sides.

High admission and prospectus requirements would not work for issuers. Start-ups are new, small, and high-risk projects. For such projects to be able to fulfil admission requirements, they should be rather low. Prospectus requirements would be too costly for start-ups.

High admission and prospectus requirements would not work for the operators of crowdfunding platforms, either. This is again related to the nature of crowdfunding websites as two-sided platforms. A crowdfunding platform cannot prevail in competition against other crowdfunding platforms unless it can attract a large number of projects and contributors. Relatively low admission and prospectus requirements are fundamental for the commercial viability of a crowdfunding platform.

Prospectus-like disclosures would not work for retail investors. Unsophisticated investors either will not read or will not understand prospectuses. Disclosures should therefore be easy to read and understand. ${ }^{167}$ Disclosures should provide basic information about the investment and risks. ${ }^{168}$

To create more value to retail investors, the quality of crowdfunding projects and start-ups should be increased. The question is how. In securities markets, the customary mechanisms include mandatory disclosures and admission requirements (sections 3.4.7 and 5.5.3). In venture capital, investors require contractual protection (section 5.3). All three would be problematic in the context of crowdfunding.

It would not be feasible to apply the practices of venture capital investors to protect crowdfunding investors. ${ }^{169}$ Such protection would not bring value to investors in most projects but would reduce the access of successful start-ups to later venture capital funding. ${ }^{170}$

167 Wroldsen JS (2013) p 632.

168 See Regulation Crowdfunding, \$227.201.

169 See nevertheless Wroldsen JS (2013) p 583 proposing substantive venture capitalist protections for crowdfunding investors.

170 Moedl M (2019) p 2 on "contractual compatibility" as "key to the question whether crowdbased financing is suitable for growth-oriented innovative ventures". 
If the customary disclosures and admission requirements do not work, and if the use of venture capital practices is not feasible in this context, other mechanisms should take their place. Ibrahim recommends "the wisdom of crowds" and "the use of reputational intermediaries". ${ }^{171}$ There can be many kinds of reputational intermediaries.

First, this function traditionally has been the domain of auditors (section 2.4.6). In the case of crowdfunding, auditing requirements would increase costs. ${ }^{172}$ Apart from reducing the obvious risk of fraud ${ }^{173}$ that even could be addressed in other ways by the platform, auditing requirements might provide false security to retail investors about the quality of the crowdfunding investment.

Second, crowdfunding platforms act as reputational intermediaries as an ancillary service. ${ }^{174}$ Generally, stock exchanges act as reputational intermediaries through admission requirements. In the case of crowdfunding, even modest acceptance requirements could suffice to reduce abuse and be a functional equivalent to auditing requirements.

Third, crowdfunding platforms can use mentoring. Mentoring is used by some traditional exchanges (section 6.4.11) for the purpose of improving the quality of issuers and increasing the number of IPOs. In crowdfunding, a mentoring programme communicated to the crowd could improve the perceived quality of issuers through its signalling effect and address the lemons problem. ${ }^{175}$ However, a mentoring programme for crowdfunding projects could increase costs and reduce the commercial viability of crowdfunding platforms. To address this problem, mentoring could be provided by a pool of selected members of the crowd.

Fourth, the crowd can be used as a reputational intermediary. The wisdom of crowds means in this case reaction to private quality signals and social media. Social media is the natural forum for the power of the crowd. Crowdfunders

171 Ibrahim DM (2015) p 593.

172 See Burkett E (2011) p 91 on US crowdfunding before the JOBS Act of 2012: "Legal costs will rise proportionally to the number of states in which an issuer sells securities. Beyond legal fees, most states require audited financial statements, which can be extremely costly. For a small-time promoter, these requirements may prove onerous. After all, legal and accounting fees must be paid before any securities are sold."

173 Williamson JJ (2013) p 2079 on how "[a]ny scam can masquerade as a start-up".

174 Ibrahim DM (2015) p 603 on the AIM's Nominated Advisers as a model: "I contend that Title III should be amended to change funding portals to make them work like Nomads. The overarching change needed in Title III is to make the funding portal's primary relationship be with startups, not investors."

175 Ibid., pp 598-603 on AIM's Nominated Advisers. 
seem to respond to signals about the quality of the project regardless of their expectations for financial return. ${ }^{176}$

Use caps. The high-risk nature of equity crowdfunding and the lack of legal protection give reason to use caps. Since crowdfunding platforms are two-sided, caps can be applied on the side of projects, on the side of investors, ${ }^{177}$ or both. They are designed to create a balance between different objectives. Various kinds of caps have been used in regulatory practice.

On the side of projects, caps can relate to funds raised from investors, the number of investors, or assets. Such caps can be qualified by the class of investors. For example, in the US, Title III companies with more than \$25 million in assets and over 500 non-accredited equity investors (or 2,000 investors of any class) are required to go public. Going public means here compliance with Section 12(g) of the Securities Exchange Act of 1934 and submission to stringent reporting and disclosure obligations.

On the side of investors, caps can lay down maximum amounts to limit people's downside exposure, ${ }^{178}$ or minimum amounts that an investor may invest to ensure that investors are wealthy enough to bear losses. Caps can relate to investments in a single project or crowdfunding projects in general.

Caps can also be qualified by space and time. Time-limited caps can facilitate staging and increase the number of funding rounds. For example, a company issuing securities in reliance on Regulation Crowdfunding in the US is permitted to raise a maximum aggregate amount of $\$ 1,070,000$ (originally $\$ 1,000,000$ ) in a 12-month period. Individual investors are limited in the amounts they are allowed to invest in all Regulation Crowdfunding offerings over the course of a 12-month period.

Some practices may work better than others.

First, a cap on assets on the side of issuers can hamper an issuer's growth and give an incentive to seek alternative ways of raising funding without such restrictions. ${ }^{179}$

176 Mollick E (2014) pp 4 and 6.

177 See, for example, Hofmann C (2018) p 229 discussing benefits on different sides, that is, benefits for companies, platforms, or non-professional investors.

178 Wroldsen JS (2017): "Yes, start-ups fail frequently, so investor caps are present to limit people's downside exposure." Section 302(a) of the JOBS Act.

179 Catalini C, Fazio C, Murray F (2016) pp 7-8: "[S]tartups with high-growth potential face an additional, significant disincentive when raising capital on Title III platforms: the requirement to go public when $\$ 25$ million in assets is reached. Public listing carries with it a number of significant additional disclosure and reporting requirements ... [T]he highest growth prospects have access to other sources of capital that do not impose these requirements. Why would startups assume these extra obligations and pressures unless they do not have an alternative?" For 
Second, caps on the side of investors can influence the management of risk through diversification. High minimum investment limits can make it more difficult for a contributor to fund many projects. High maximum investments limits might not encourage investors to be diversitied. High minimum and low maximum investment limits nudge contributors to manage risk by investing in noncrowdfunding assets.

Third, maximum investment limits on the side of investors cannot be effective unless each crowdfunding offering is exclusively conducted through one platform. The platform is better placed to determine whether the limits are complied with. The issuer should be able to rely on the work of the platform. ${ }^{180}$

Fourth, caps on the side of investors can lead to adverse selection when investors are divided into different classes. For example, Title II of the JOBS Act removed the ban on general solicitation under Rule 506 provided that only accredited investors are solicited. Title II is regarded as a success. ${ }^{181}$ Title III of the JOBS Act applies even to retail investors. It is not regarded as a success, because successful start-ups are expected to choose Title II offerings. To address this problem, a solution could be to replace the two categories with one category or make Title II available to a larger group of investors. This was recommended in an MIT policy report that went on to describe the benefits of the "substantially more flexible approach" of the Financial Conduct Authority (FCA) in the UK: "According to the regulator's most recent evaluation of the regime, the UK rules have been successful so far not only in letting the market grow and experiment, but also in protecting and educating retail investors." ${ }^{182}$

In any case, caps can be designed to strike a balance between various conflicting objectives. According to the MIT policy report, the balance struck by the

AIFMD, see Building a Capital Markets Union. European Commission, Green Paper, COM(2015) 63 final, section 4.2, pp 16-18: "A particular concern that has been raised is that managers whose portfolio exceeds $€ 500$ million cannot apply to set up and operate such a fund, nor can they use these designations to market the funds in the EU. Widening the range of market participants could potentially increase the number of EuVECA and EuSEFs available.”

180 This is the case in the US. See Regulation Crowdfunding: A Small Entity Compliance Guide for Issuers (May 13, 2016) prepared by the staff of the SEC: "Each Regulation Crowdfunding offering must be exclusively conducted through one online platform. The intermediary operating the platform must be a broker-dealer or a funding portal that is registered with the SEC and FINRA. Issuers may rely on the efforts of the intermediary to determine that the aggregate amount of securities purchased by an investor does not cause the investor to exceed the investment limits, so long as the issuer does not have knowledge that the investor would exceed the investment limits as a result of purchasing securities in the issuer's offering."

181 Ibrahim DM (2015) pp 565 and 582; Catalini C, Fazio C, Murray F (2016) p 12.

182 Catalini C, Fazio C, Murray F (2016) p 12, referring to FCA (2015b) on UK regulatory practice. 
Title III rules is "thoughtful as well as substantive", but two fundamental questions remain. The first is whether the rules "encourage investors to be properly diversified" given the relatively small investment limits. The second is whether Title III platforms are likely to "attract the next generation of 'unicorns' ( $\$ 1$ billion startups) and offer real opportunities for everyday investors to share in their returns". ${ }^{183}$

Permit pooling for retail investors. It should be made possible to pool investments even where contributors are retail investors.

Pooling is restricted in the US. While Title II the JOBS Act of 2012 facilitates the pooling of equity crowdfunding for accredited investors, Title III restricts pooling for non-accredited investors. However, there should be room for innovation and competition between alternative business models in crowdfunding.

Pooling is an alternative way to organise contributors' investments. It can sometimes benefit both start-ups and contributors and make crowdfunding more attractive to both.

For example, pooling can be used to anticipate future funding rounds and help the start-up to negotiate with venture capital funds. Pooling can also help to manage contributors' rights (with direct or indirect share ownership in the start-up) and how shareholders' rights can be exercised (individually or collectively). Moreover, permitting pooling might help contributors to invest in a larger number of projects and diversify their investments.

This said, the administration of pooling will increase costs. Pooling might not have any major effect on contributors' financial security. If contributors want to manage risk through diversification, there are easier ways than the pooling of inherently high-risk and low-quality crowdfunding investments. Retail investors can look for investment opportunities outside crowdfunding. ${ }^{184}$

Create new secondary markets and a new company form. Equity crowdfunding lacks a secondary market. The lack of a secondary market tends to hamper the primary market. One may ask whether secondary trading in equity crowdfunding investments should be liberalised. Past experiences indicate that the answer is no.

There was a failed seven-year experiment in the 1990s under Rule 504 of Regulation D. Burkett has described it as follows: "In 1992, the SEC amended Rule 504 of Reg D to drastically reduce the restrictions on small issuers, who could then make general solicitations and sell securities that could be freely

183 Catalini C, Fazio C, Murray F (2016) p 6.

184 See nevertheless Williamson JJ (2013) p 2079 on pooling as a way of diversification in the crowdfunding market. 
traded on the open market. The SEC's rationale was that 'the size and local nature of these small offerings did not appear to warrant imposing extensive federal regulation.' However, seven years later, the SEC reversed course and readopted the pre-1992 restrictions. This reaction was prompted by a surge of 'pump and dump' schemes perpetuated by unscrupulous promoters. Given this example, the SEC may suffer from a 'once bitten, twice shy' attitude toward small-issuer concerns." 185

Problems caused by the inherently low quality of equity crowdfunding investments and the fact that they are sold to unsophisticated retail investors cannot be cured by high listing requirements and disclosures. ${ }^{186}$

This said, there could be an alternative. Secondary markets could be created with the help of microexchanges (Chapter 8). The nature of equity investments as credence goods could partly be mitigated by requiring from the company a track record as a condition for the use of a microexchange. ${ }^{187}$ The low quality of equity crowdfunding investments and the risk of a lemons market could partly be addressed by creating a new company form - the small public limited-liability company (Chapter 9) - for start-ups that fulfil certain minimum requirements and want to use the proposed microexchange.

The availability of a new company form (the small public limited-liability company) and a new trading mechanism (the microexchange) could increase the popularity of crowdfunding. They could make crowdfunding more attractive to higher-quality start-ups and their early investors that plan future funding rounds in four ways.

First, they could give some good crowdfunding start-ups a new goal and make them look more serious in the eyes of investors. As it stands, direct equity crowdfunding investments in start-ups do not provide long-term financial security for retail investors. But a start-up needs funding in any case. Some early investors might prefer retail investors to follow them into start-ups. ${ }^{188}$ Where a

185 Burkett E (2011) p 96. See also Wroldsen JS (2013) pp 603-606.

186 Wroldsen JS (2013) pp 603-606: “Therefore, continuing to apply a purely disclosure-based philosophy to crowdfunding investment is flawed because it places excessive trust in the power of disclosure to protect crowdfunding investors." Gabison GA (2015) pp 368-370: "Fraud, incompetence, and lack of exit strategies jeopardize equity crowdfunding. Fraud constitutes the biggest threat to crowdfunding because traditional reputational and legal enforcement methods may not work."

187 Ibrahim DM (2013) p 253: "Most market investors are not interested in funding start-ups due to their lack of a track record, high failure rate, and lack of liquidity. However, two types of investors do specialize in these investments: angel investors and VCs.”

188 Ibrahim DM (2015) p 592: "Even without these investment caps, I have argued that part of the Internet's attraction for accredited investors is the ability to add tag-along passive investors 
start-up has survived the early years (thanks to crowdfunding, ${ }^{189}$ angel investors, luck, or otherwise), liquidity and suitability for retail investors could be increased by making it possible for the start-up to re-incorporate as a small public limited-liability company that uses a microexchange to facilitate trading. Re-incorporation should be made easy. In the long term, the availability of a new trading mechanism might increase the number of companies with publicly-traded shares. ${ }^{190}$

Second, more likely future access to public trading could make it more meaningful to use new venture capital or crowdfunding instruments such as convertible securities (SAFEs or convertible notes). ${ }^{191}$ Convertible securities have not been suitable for crowdfunders in the past. ${ }^{192}$

Third, the availability of secondary trading and access to public markets could help to reduce dependence on venture capital in later funding rounds.

Fourth, where venture capital is the preferred form of funding in later funding rounds, standardisation by means of a new company form could help to reduce the risk of contractual incompatibility, that is, the risk that the legal framework of the crowdfunding investment is not aligned with the requirements of venture capital investors in a future funding round. ${ }^{193}$

Cross-border transactions. Both access to funding and the level of investor protection can depend on whether cross-border transactions are permitted.

at a low cost. In other words, accredited investors want unaccredited investors to follow them into startups."

189 Hofmann C (2018) p 228: "Taken to extremes, gullible retail investors in such companies may serve as 'guinea-pigs', testing the waters for recipients of funding and professional investors alike. This is the case because a company that survives the critical, initial phase of its existence can then rely on more traditional funding options from angel investors, venture capitalists, and banks."

190 Heminway JM (2017) p 211: "Both the lack of existence of a resale market and support for an unsustainable resale market may have adverse effects on the markets involved in equity crowdfunding."

191 Green JM, Coyle JF (2016) pp 174-176: "Of the 96 issuers to launch crowdfunding offerings through August 31, 2016, 30 issuers (approximately 31\%) chose to offer convertible securities (such as convertible notes, SAFEs, or similar instruments) to prospective crowdfunding investors. Ninety percent of the convertible securities used were SAFEs. The remaining convertible securities were convertible notes.”

192 Green JM, Coyle JF (2016) pp 174-176.

193 Moedl M (2019) p 2: "As venture capital typically invests higher amounts than crowd campaigns could raise ... and also serves as a door opener for the important resources besides capital ..., contractual compatibility may ultimately be key to the question whether crowd-based financing is suitable for growth-oriented innovative ventures." 
There should be constraints on cross-border equity crowdfunding. Such constraints can be a way to balance conflicting objectives.

On one hand, the liberalisation of cross-border transactions could increase equity crowdfunding. Especially in small markets, cross-border transactions could help to increase the number of investors or projects to invest in.

On the other, equity crowdfunding is akin to betting. In the absence of an efficient legal mechanism to increase the quality of these inherently low-quality and high-risk investments, local forms of control become more important. Investors may benefit from a favourable business culture, social norms, social media, and general civil and criminal law remedies in the start-up's country. Where projects and investors are located in different countries, such local forms of control will not work for investors and the risk of abuse is increased.

The protection of retail investors should prevail in the context of cross-border equity transactions. At the end of the day, start-ups that turn to crowdfunding may not need much money. The funds should be available in the domestic market. Local start-ups may even benefit from local monitoring by investors and the platform.

Constraints on cross-border transactions can take many forms. They can be direct or indirect. Direct constraints can include: applying registration or authorisation requirements to crowdfunding platforms; reserving the use of the platform to companies in the same country; limiting the activities of foreign crowdfunding platforms; and applying more stringent registration or disclosure requirements to foreign companies. Indirectly, cross-border transactions can be hampered by the existence of different regulatory regimes in different countries and the modalities of cross-border transactions.

Constraints on cross-border transactions can improve the efficiency of caps. Caps in a certain country restricting the subjective crowdfunding activity of a contributor may be less effective where the contributor even can invest in foreign securities. The efficiency of such caps can be increased by restricting cross-border transactions or by integrating national markets so that investment behaviour can be monitored regardless of where in the region the contributor is located.

There are differences between the US approach and the EU approach regarding cross-border transactions. In the US, the approach is restrictive. In the EU, the Regulation on European Crowdfunding Service Providers (ECSP) for Business is designed to facilitate the operation of cross-border crowdfunding platforms.

In the EU, crowdfunding markets outside the UK largely have been small and domestic. ${ }^{194}$ The purpose of the ECSP Regulation is to contribute to an internal

194 European Commission (2017c). 
market by providing a single set of rules and a single authorisation for cross-border crowdfunding platforms. ${ }^{195}$

There are direct constraints in the US. For example, the SEC has concluded that non-US issuers may present unique risks that would make them unsuitable for the scaled regulatory regime associated with crowdfunding. An issuer must therefore be organised under, and subject to the laws of a state or territory of the United States or the District of Columbia.

There are also indirect constraints on cross-border transactions in the US. In a 2011 article, Burkett described the effect of differences in US state laws on US crowdfunding as follows: "Even if an issuer qualifies for an exemption from federal registration requirements, it likely still must comply with state registration requirements in every state in which it intends to offer or sell securities. This creates problems in the context of investment crowdfunding because it means that an issuer would have to screen potential funders based on their residency. Furthermore, it creates a tension, if not a paradox, between the viability of the offering and the costs of even making the offering. After all, the offer will be more viable if available in more states, but more states mean higher costs. Small-time promoters may only be able to afford to register in a few states, which may jeopardize the viability of their offerings. Larger intermediaries might be able to bear some of these costs, but the million-dollar limit might make a broadly available offering infeasible given the fixed costs."196 Moreover, Burkett mentioned legal costs: "Legal costs will rise proportionally to the number of states in which an issuer sells securities. Beyond legal fees, most states require audited financial statements, which can be extremely costly. For a small-time promoter, these requirements may prove onerous. After all, legal and accounting fees must be paid before any securities are sold." ${ }^{97}$

Payments and settlement. Equity crowdfunding investors make payments and expect to receive shares in return. Risk is reduced in two ways.

The first relates to funding targets. The "all-or-nothing" approach can be used to ensure that the project is not undercapitalised. ${ }^{198}$

The second relates to the holding of funds. If the two sides of the transaction do not happen simultaneously, parties are exposed to a counterparty risk. An intermediary can be used for the management of payments and settlement between the parties. In such a case, the funds should be protected against the insolvency of the intermediary.

195 Recital 7 of Regulation (EU) 2020/1503 (ECSP Regulation).

196 Burkett E (2011) pp 89-90.

197 Ibid., p 91 on US crowdfunding.

198 Hofmann C (2018) pp 226-227. 


\subsection{Conclusions}

Equity crowdfunding is facilitated by new regulation. However, equity crowdfunding creates problems for regulators. The default approach is to assume that investors should be protected. However, one may ask to what extent contributors should be protected as investors in the light of the fact that equity crowdfunding is not a reasonable form of investment but could be seen as a form of consumption. If contributors are protected by the regulatory regime that applies to the public offering of securities in general, retail investors may be misled about the high-risk nature of equity crowdfunding.

The volume of crowdfunding is low, but there are many crowdfunding platforms. In the future, there could be consolidation. The drivers of consolidation may include the need to create positive network effects, the cost of regulatory compliance, and the interests of large financial intermediaries. Large financial intermediaries might take over operators of crowdfunding platforms. ${ }^{199}$

This said, there could be reasons for large financial intermediaries to avoid equity crowdfunding. First, there is the question of volume. Low volumes are an obvious reason to stay out of the business. Second, cross-selling opportunities might be hampered by the nature of equity crowdfunding. Start-ups that raise crowdfunding are high-risk investment targets, and equity crowdfunding could be seen as a form of consumption rather than investment. Third, there is a question of regulatory compliance. Large financial intermediaries must comply with fiduciary requirements in the provision of customer advice and the marketing and selling of financial products and services. ${ }^{200}$ It might be difficult for large financial intermediaries to ensure compliance with the customary fiduciary requirements in relation to the same customers when selling both traditional investment products (that can provide financial security) and equity crowdfunding products (that cannot provide financial security). Financial intermediaries may not want to compromise regulatory compliance. Fourth, large financial interme-

199 Deutsche Börse AG, Celent (2016) pp 15-16: “[C]rowdfunding has emerged as a viable form of alternative financing for many startups and individual investors. Nonetheless, as the space becomes increasingly institutional, it is increasingly capturing the eye of regulators in the US and Europe. A merger of alternative funding platforms with firms with strong regulatory relations looks to be the future ... There is nothing precluding large market infrastructure providers from leveraging their market operation expertise in financial and large corporate domains, in order to act as the point of encounter between idle capital in hands of private investors and cash-rich corporations, and the need for growth capital from small businesses across the world. This is a trend for financial market infrastructure organizations to capitalize on for many years, providing new solutions to the market in the realm of funding and financing." 200 See, for example, Articles 24 and 25 of Directive 2014/65/EU (MiFID II). 
diaries might prefer not to compromise their reputation in the investment business.

While there is much hype around equity crowdfunding, crowdfunding is not the proper means to increase the number of companies with publicly-traded shares and retail investors' direct equity investments.

\section{References}

Burkett E (2011) A Crowdfunding Exemption? Online Investment Crowdfunding and U.S. Securities Regulation. Tennessee Journal of Business Law 13:63-106

Catalini C, Fazio C, Murray F (2016) Can Equity Crowdfunding Democratize Access to Capital and Investment Opportunities? MIT Innovation Initiative. Lab for Innovation Science and Policy Report. Massachusetts Institute of Technology

Chiu IHY, Greene EF (2019) The Marriage of Technology, Markets, and Sustainable (and) Social Finance: Insights from ICO Markets for a New Regulatory Framework. European Business Organization Law Review 20(1):139-169

Coyle JF, Green JM (2014) Contractual Innovation in Venture Capital. Hastings Law Journal 66:133-183

Coyle JF, Green JM (2017) Startup Lawyering 2.0. North Carolina Law Review 95(5):1403-1432

Cumming DJ, Hornuf L, Karami M, Schweizer D (2016) Disentangling Crowdfunding from Fraudfunding. Max Planck Institute for Innovation \& Competition Research Paper No. 16-09, August 2016

Deutsche Börse AG, Celent (2016) Future of Fintech in Capital Markets, 20 June 2016

Dorfleitner G, Hornuf L, Weber M (2017) Dynamics of Investor Communication in Equity Crowdfunding. Max Planck Institute for Innovation \& Competition Research Paper No. 17-06, May 2017

European Commission (2017c) Economic Analysis Accompanying the document Communication from the Commission to the European Parliament, the Council, the European Economic and Social Committee and the Committee of the Regions on the Mid-Term Review of the Capital Markets Union Action Plan. Commission staff working document, SWD(2017) 224 final, 8 June 2017

European Crowdfunding Network AISBL (2017) Review of Crowdfunding Regulation 2017: Interpretations of existing regulation concerning crowdfunding in Europe, North America and Israel. European Crowdfunding Network AISBL, Brussels

FCA (2015b) A review of the regulatory regime for crowdfunding and the promotion of nonreadily realisable securities by other media. Financial Conduct Authority, London

FCA (2018) Loan-based ('peer-to-peer') and investment-based crowdfunding platforms: Feedback on our post-implementation review and proposed changes to the regulatory framework. Financial Conduct Authority, Consultation paper CP 18/20, London

FESE (2018) FESE Position on the Proposal for a Regulation on European Crowdfunding Service Providers (ECSP) for Business, 31 October 2018

Gabison GA (2015) Equity Crowdfunding: All Regulated but Not Equal. DePaul Business and Commercial Law Journal 13(3):359-409 
Gilson RJ (2003) Engineering a Venture Capital Market: Lessons from the American

Experience. Stanford Law Review 55:1067-1103

Green JM, Coyle JF (2016) Crowdfunding and the Not-So-Safe SAFE. Virginia Law Review Online 102:168-182

Heminway JM (2017) Selling Crowdfunded Equity: A New Frontier. Oklahoma Law Review 70(1):189-213

Herdrich N (2015) Just Say No to Crowdfunding. University of Puerto Rico Law Review 6(2):157 $-177$

Hofmann C (2018) An Easy Start for Start-ups: Crowdfunding Regulation in Singapore. Berkeley Business Law Journal 15(1):219-267

Hornuf L, Klöhn L, Schilling T (2018) Financial Contracting in Crowdinvesting: Lessons from the German Market. German Law Journal 19(3):509-578

Hornuf L, Schilling T, Schwienbacher A (2019) Are Equity Crowdfunding Investors Active Investors? Max Planck Institute for Innovation \& Competition Research Paper No. 19-15; CESifo Working Paper No. 7884

Ibrahim DM (2013) Should Angel-Backed Start-Ups Reject Venture Capital? Michigan Journal of Private Equity and Venture Capital Law 2(2):251-269

Ibrahim DM (2015) Equity Crowdfunding: A Market for Lemons? Minnesota Law Review 100:561-607

Kitch EW (2014) Crowdfunding and an Innovator's Access to Capital. George Mason Law Review 21:887-894

Klöhn L, Hornuf L, Schilling T (2016) The Regulation of Crowdfunding in the German Small Investor Protection Act: Content, Consequences, Critique, Suggestions. European Company Law 13(2):56-66

Moedl M (2019) Two's a Company, Three's a Crowd: Deal Breaker Terms in Equity Crowdfunding for Prospective Venture Capital. Max Planck Institute for Innovation \& Competition Research Paper No. 18-25, April 2019

Mollick E (2014) The Dynamics of Crowdfunding: An Exploratory Study. Journal of Business Venturing 29(1):1-16

OECD (2015c) New Approaches to SME and Entrepreneurship Financing: Broadening the Range of Instruments. OECD Publishing, Paris

SEC (2016b) Regulation Crowdfunding: A Small Entity Compliance Guide for Issuers. Prepared by the staff of the SEC. May 13, 2016 (with April 5, 2017 updates to reflect inflation adjustments to the dollar amount thresholds)

UNDP (2017) Financing Solutions for Development - Crowdfunding

Williamson JJ (2013) The JOBS Act and Middle-Income Investors: Why It Doesn't Go Far Enough. Yale Law Journal 122(7):2069-2080

Wroldsen JS (2013) The Social Network and the Crowdfund Act: Zuckerberg, Saverin, and Venture Capitalists' Dilution of the Crowd. Vanderbilt Journal of Entertainment and Technology Law 15(3):583-635

Wroldsen JS (2017) Crowdfunding Investment Contracts. Virginia Law \& Business Review 11(3):543-612

Zetzsche DA, Preiner C (2018) Cross-Border Crowdfunding: Towards a Single Crowdlending and Crowdinvesting Market for Europe. European Business Organization Law Review 19:217-251 
Ziegler T, Sneor R, Wenzlaff K, Odorović A, Johanson D, Hao R, Ryll L (2019) Shifting Paradigms: The $4^{\text {th }}$ European Alternative Finance Benchmarking Report. Cambridge Centre for Alternative Finance, Cambridge 